Meta

Journal des tradlucteurs

Translators' Journal

\title{
Evolution in Translation since 1966 as Reflected in the Pages of META
}

\section{Roda P. Roberts}

Volume 30, numéro 2, juin 1985

URI : https://id.erudit.org/iderudit/003957ar

DOI : https://doi.org/10.7202/003957ar

Aller au sommaire du numéro

Éditeur(s)

Les Presses de l'Université de Montréal

\section{ISSN}

0026-0452 (imprimé)

1492-1421 (numérique)

Découvrir la revue

Citer cette note

Roberts, R. P. (1985). Evolution in Translation since 1966 as Reflected in the Pages of META. Meta, 30(2), 194-198. https://doi.org/10.7202/003957ar d'utilisation que vous pouvez consulter en ligne.

https://apropos.erudit.org/fr/usagers/politique-dutilisation/ 


\section{EVOLUTION IN TRANSLATION SINCE 1966 AS REFLECTED IN THE PAGES OF META*}

Since the battle of the 50's about whether translation should be considered a literary operation or a linguistic operation, it has been generaily recognized over the years that translation is a branch of applied linguistics. Therefore any examination of the evolution of applied linguistics, which is the theme of this symposium, must necessarily include a study of the evolution of translation - all the more so since, in my opinion, it is the branch of applied linguistics that has perhaps developed the most and the most rapidly over the last couple of decades.

The very speed of the growth of translation and the many, different changes in the translation world, not only in Canada but also internationally, have made it difficult for any one person to keep up with the latest developments, tendencies and ideas. But through all the changes and developments on the translation scene, the one constant has been $M E T A$, the Canadian translator's information and research periodical published four times a year. If, then, it is possible to trace accurately the main changes in translation, especially if not uniquely in Canada, it is in large part due to this journal, which has not only witnessed the birth of many translation institutions and tendencies but has also survived the death of some of the institutions, trends and personages that marked the earlier stages of the development of translation.

META was born in 1966 as the successor to the ten-year old TRANSLATORS' JOURNAL / JOURNAL DES TRADUCTEURS. In a letter sent in 1966 to subscribers to the former TRANSLATORS'JOURNAL, the editor Jean-Paul Vinay, presenting the new $M E T A$, the publication of which was to be handled by the Presses de l'Université de Mont- 
gering assumption that if "they" choose to settle in Australia, they should learn English.

This difference manifests itself also in the area of interpreter/translator salaries, currently unfairly low. Although it has set up a system which, while not being ideal, has considerably improved the situation, NAATI is powerless to dictate but can only encour. age the employment of certain levels of interpreters/ translators in certain positions. It cannot therefore recommend salary structures. This situation does nothing to improve the question of "professionalisation".

\section{CONCLUSION}

The present period for interpreting/ translating in Australia is characterised both by vast changes and some despondency. The problems may not be unusual for a profession in the process of becoming. However there is also hope that new areas of activity will be opening up for interpreting/ translating in Australia to bring it closer to the international model. But before that happens the present lacunae need to be filled, and although that will take time, there is evidence that most governments, Federal and State, are, if slowly, beginning to take more seriously their responsibilities in this area.

\section{ADOLFO GENTILE}

* I would like to express my gratitude to Jill Blewett, South Australian College of Advanced Education for her helpful comments and suggestions.

\section{APPENDIX I}

\section{COPQ 1974}

\section{Terms of Reference}

1. to define the terms "interpreter" and "translator" and their relationship with one another and the relationship between "interpreting" and linguistic skill ;

2. to define the range of tasks for which interpreters and translators are needed in Australia ;

3. to establish the level of skills, education and/or experience required for each of these tasks

4. to recommend ways of testing and accrediting/certificating interpreters and translators competent for each of the tasks identified ;

5. to identify appropriate means of providing training for future interpreters and translators:

6. to identify appropriate ways of up-grading the skills of existing practitioners where needed.

\section{APPENDIX II}

Terms of Reference - NAATI : 1978 be to :

The principal objectives of the Authority will

(i) Establish the standards and conditions leading to professional status, and in so doing de- velop translating and interpreting in Australia to meet community needs.

(ii) Develop the basic infrastructure for the emergence of a national self-regulatory professional body in the expectation that this body would, within five years, assume responsibility for the profession, including accreditation.

To this end NAATI will :

a) Determine levels of skills for translators and interpreters appropriate to Australian conditions, taking into account the recommendations of the COPQ Working Party.

b) Provide advice and guidance on the content of courses to tertiary institutions which are conducting or planning courses in translating and interpreting so that graduates of such courses will be eligible for accreditation at the level determined for that course by NAATI.

c) Develop tests and any other procedures necessary to assess and provide a means of accreditation for those who, with or without formal qualifications obtained in Australia or elsewhere, are practising or wish to practise as translators or interpreters in Australia ; such procedures may include bridging study or supervised field training approved by the Authority.

d) Provide a means of accreditation for those who have successfully completed courses at various levels based on standards of competence established by the Authority.

e) Monitor changing Australian needs for interpreter/translator services and advise on the development of training programmes throughout Australia to meet these needs.

f) Take action to encourage employing authorities to require as a prerequisite for appointment accreditation by NAATI.

g) Maintain a public register of translators and interpreters who meet the standards established by the Authority.

h) Report annually to the Minister for Immigration and Ethnic Affairs on the work of the Authority.

\section{APPENDIX UII}

INTERPRETER/TRANSLATOR TRAINING COURSES : AUSTRALIA 1982

\section{ACCREDITED}

LEVEL I

- Language aide (Italian, Greek) at Casuarina High School, Darwin, Northern Territory.

- Language aide and interpreter (Aranda, Ngarrka and Western Desert Groups) at Institute for Aboriginal Development, Northern Territory. 
real, assured readers that the Editorial Board would continue to publish the same "organ of research and information in the field of translation and interpretation" as it had in the past and that readers would continue to find in the pages of $M E T A$ the "articles you are accustomed to reading, treated even more fully than in the past" (Vinay 1966).

This assurance, or perhaps prophecy, has only been partially realized, for translation in the generic sense has evolved so considerably since 1966 that META, while retaining its original basic aims, has itself necessarily changed to reflect the changes in the field covered. The changes it reflects are diverse, but they can be grouped broadly into three main categories : (a) an increased interest in writing about translation; (b) the broadening of the scope of translation; (c) changes in attitudes toward specific aspects of translation. These three broad categories of changes warrant analysis.

The increased interest in writing about translation is clearly revealed by a purely statistical study of META volumes from 1966 to 1984. In 1966, the average length of each volume (comprising four issues) was 200 pages ; the average length today is over 400 pages. In under twenty years, META has in fact doubled in size. This increase in the quantity of texts published on translation obviously did not take place overnight. The following table indicates the key periods of increase in volume.

$\begin{array}{ll}\text { Year } & \text { Volume } \\ 1966 & 200 \\ 1969 & 250+ \\ 1975 & 300+ \\ 1980 & 400+\end{array}$

While it is interesting to speculate on the reasons for the growth of META at certain specific periods (e.g. 1969 marks the passage of the Official Languages Act in Canada and the resultant development of several translation programmes; 1975 marks increased francisation activity in Quebec following the Loi sur la langue officielle of 1974), it is impossible to present definite explanations concerning the increase in the size of META at these specific times on the basis of the content of META itself. What can be asserted definitely is that, over the years, an increasing number of texts have been written on translation, which has warranted a corresponding increase in the size of META. In other words, not only have more and more people been performing translation activities, but larger numbers of them have been reflecting on their professional activities and have put down their views on paper.

The increase in the number of contributors to $M E T A$ can be confirmed by a quick glance at the table of contents of each issue. In the 1960's, there were only a handful of contributors, many of them members of the Editorial Board or "Corresponding Members" of META, and the same names reappeared not only from one issue to the next, but often twice or thrice in the same issue. For instance, two members of the Editorial Board of META contributed three and two articles respectively to $M E T A$, Vol. 13, No 3, September 1968. Since the mid-seventies, it is rare to find more than one contribution by a given individual in the same issue, which means necessarily that the number of contributors has increased sufficiently to allow the pages of META to be filled without having constant recourse to a few active researchers.

A second glance at the ever-growing list of contributors also reveals another significant fact : the profile of those writing on translation has changed significantly over the years. Whereas, in the early days of META, the contributors were by and large Canadians, most of whom lived along the Quebec/ Montreal/Ottawa axis, with the majority centered in Montreal, by the late seventies, there were more frequent contributions made by Canadians from outside the traditional "translation centers" of Canada - from Toronto, Calgary and Fredericton, to name just a few cities. This new trend no doubt reflects the spread of translation activity throughout Canada.

Another development indicated by the list of contributors is that, by the mid-seventies, at least every second issue contained one text by a nonCanadian - a trend which has accelerated in the 1980's. This trend gives rise to several hypotheses. On the one hand, it would suggest that reflection and writing on translation is on the rise abroad, as it has been in Canada. On the other, it would indicate that the Canadian translation world, having overcome its own growing pains, has gradually become more open to the world translation scene. What seems certain is that the Canadian translation milieu and its organ META have become a recognized force in the world - important enough for non-Canadians to wish to have their views known in Canada and, through META's foreign subscribers, in the four corners of the world.

The ever-growing, worldwide interest in translation is no doubt linked to the second category of change revealed by META : the broadening of the scope of translation. Translation in 1966 was used mainly as a generic term covering two primary activities : written translation (termed "translation") and oral translation (or "interpretation"). When $M E T A$ was founded, it was subtitled - as was its predecessor the TRANSLATORS' JOURNAL - an "organ of research and information in the fields of translation and interpretation" (Vinay 1966). While problems of "lexicology" were of interest to META (Vinay 1966) and were regularly covered in the section "Problèmes et solutions", which was published in each issue as of June 1967, lexicology then seemed to be considered only as a necessary part of translation and interpretation and, as such, did not merit special mention in the subtitle of META. But is was already clear as of 1966 that a specific aspect of lexicology, terminology, that deals with specialized vocabulary, was coming into its own. From the pages of "Problèmes et solutions", which contained texts on vocabulary related to transformers, laundry and a myriad of 
other specialized fields of human activity, terminology quickly made its way onto the front pages of $M E T A$, first indirectly, under the guise of documentation (cf. G. Dubeau, P. Tessier and J.-P. Vallée (1966) : "la Documentation du traducteur", META, Vol. 11, No 3, September) and then openly, in December 1967, when a special issue Aspects de la terminologie was published. This early special issue was more modest than more recent ones : it consisted of only two major articles on the subject. However, it marked the beginning of a long series of articles on terminology, and more particularly terminology banks, in the late 1960's and early 1970's. Terminology became an acknowledged subfield of translation in the generic sense in the 1970's, and in 1980 this was finally recognized officially by $M E T A$, which became explicitly an "organe d'information et de recherche dans les domaines de la traduction, de la terminologie et de l'interprétation".

The development of term banks, duly noted and presented in META as of Vol 14, No 4, December 1969, went hand in hand with another major development in translation : the use of computers. The first mention of computers in META is found in its very first year of existence (Vol. 11, No 3, September 1966) in the section "l'Actualité", which reproduced a communique found in the Toronto Globe and Mail entitled "World Automation : The Bilingual Computer." This was followed the next year (Vol. 12, No 2 , June 1967), again in "l'Actualitê", by a summary of another newspaper article on the subject of computers and translation and by the reporting of an announcement in Transmondia of IBM's experimental machines intended for Russian-English and ChineseEnglish translation. The next issue of META (Vol. 12, No 3, September 1967) presented a report of a symposium on machine translation organized by the Société des traducteurs et interprètes du Canada. And from then on, the computer made regular appearances in META, either directly through reports in "l'Actualité" or major articles such as the one on METEO in June 1976, or indirectly through the many reports and articles on term banks. And, as in the case of terminology, the ever-growing role of computers in translation activities was finally recognized by META in 1981 by the publication of a special issue entitled l'Informatique au service de la traduction / Machine Aids to Translation.

A similar broadening of the scope of translation is seen in the growing place occupied by documentation in META. It was already abundantly clear in 1966 that translators needed suitable reference material to carry out their tasks, and this need was met by META through a separate section "les Outils du traducteur", which informed them about appropriate publications, and through occasional articles on the subject, such as the one by G. Dubeau et al. cited above. However, the more active involvement of translators in selecting documentation and in building up translator-oriented libraries led to the publication of yet another special issue of META specifically on documentation in March 1980.
The broadening of the scope of translation, as reflected by $M E T A$, has not been limited to the development of new subfields of translation. What is just as worthy of note has been the growing tendency to apply new developments in other fields to the analysis of translation. In the 1960 's, translation was studied most often in terms of stylistics - which explains why Jean-Paul Vinay in his letter of 1966 presenting META to subscribers of the TRANSLATORS" JOURNAL said : "META is a journal devoted to the problems of translation, interpretation, lexicology and stylistics." In fact, "Stylistique et transformation" by Jean-Paul Vinay was the first article in the very first issue of META, (Vol. 11, No 1 , March 1966), and comparative stylistics as developed by Charles Bally, Alfred Malblanc, Jean-Paul Vinay and Jean Darbelnet continued to influence theoretical reflection found in $M E T A$ for many years to come (e.g. A. Clas "Subjectivisme - Objectivisme", META, Vol. 13, No 3, September 1968; W. Bryant, "A Comparison of Translation Styles", META, Vol. 17, No 3, September 1972 ; B.T. Hanna, "Samuel Becket : traducteur de lui-même", META, Vol. 17 , No 4, December 1972 ; J. Darbelnet, "Lexicologie différentielle : champ et méthode", META, Vol. 18, Nos 1-2, March-June 1973; Y. Saint-Pierre Farina, "l'Expressivité : essai de définition", META, Vol. 18, No 3, September 1973). Although comparative stylistics still continues to play an important role in translation studies - a fact marked by the recent publication in META (Vol. 28 No 3, December 1983) of two texts by Jean-Paul Vinay and Jean Darbelnet on the occasion of the twenty-fifth anniversary of their world-renowned work Stylistique comparee $d u$ francais et de l'anglais - attempts have been made since the early 1970's to explain translation by means of other developments in the field of linguistics : componential analysis (M.E. Landsberg, "Translation Theory : An Appraisal of Some General Problems", META, Vol. 21, No 4, December 1976); text analysis and semiotics (J. House, "A Model for Assessing Translation Quality", META, Vol. 23, No 2, June $1977 ;$ K.J. Kuepper, "Literary Translation and the Problem of Equivalency", META, Vol. 22, No 4, December 1977).

Even more eye-catching developments are indicated by titles such as "A Psychological Approach to Simultaneous Interpretation" (META, Vol. 20, No 2, June 1975), Psychanalyse et traduction (META, Vol. 27, No 1, March 1982 - special issue) and Cerveau, langage et traduction (META, Vol. 29, No 1, March 1984 - special issue). Such articles and special issues, produced most often not by translators, but by specialists in other fields traditionally neglected by translators, attempt to relate translation to other disciplines. As François Peraldi notes in the first article of Psychanalyse et traduction :

C'est ici, au niveau de la théorisation, que la question du rapprochement de la psychanalyse et de la traduction se présente sous un jour très différent de l'obscurantisme, quelque peu cari- 
catural, sous l'angle duquel je l'ai introduite. En effet, ce dont les traducteurs et les psychanalystes doivent produire la théorie, s'ils veulent faire l'effort de penser leur pratique, c'est une seule et même chose: le langage du sujet humain.

Are translators ready for these new horizons? Are they prepared to put aside their daily, routine practical activities long enough to grasp the new ideas, the new trends, the new inventions presented by META? This would seem to be the case if one considers that META's subscription list continues to grow, even though it has devoted less space over the years to the daily life of translators and translators' associations and more space to more theoretical ideas and important terminological and linguistic problems. " $L$ 'Actualité", a catch-all section that covered the activities of the various translators' associations, that announced the birth of different translation schools and translation services, and the death of famous personages in the translation world, and both announced and reported on all translation conventions big and small, slowly lost ground in $M E T A$. Where, in the first year of META's existence, if followed immediately after the major articles, it was soon relegated (in 1967) to the end of the issue While the section continued to exist until 1982, its content became increasingly restricted to reports of important national and international conventions, until it disappeared altogether to make way for a new section, "Bloc-notes", which, while continuing to report on important congresses, consists mainly of short articles on clearly delineated topics of a more practical nature than those treated in the major articles. While the disappearance of "l'Actualité" has been regretted by some readers, in my opinion it symbolizes a significant evolution. In the 1960's and even in the 1970's, translation was still fighting for its rightful place in the sun as a profession worthy of note. At that time, it was important to announce to the world every professional activity of the translators' associations, every new translation course and school. However, in the 1980's, few would dare to contest the fact that translation is a profession. There is no psychological or philosophical need, therefore, for "l'Actualité", and the information bulletins put out by the translators' associations - bulletins whose birth and existence were announced in "l'Actualité $^{\prime \prime}$ - more than adequately fill the daily information needs of translators. The disappearance of "l'Actualité" denotes, to my mind, a change in attitude towards translation, which is now universally recognized as a profession.

Another, totally different, indication of the changing attitudes is reflected in the texts pertaining to machine aids in translation. While it was indicated earlier that computers and their role in translation have been increasingly discussed in META over the years, what remains to be shown is the change in attitude on the part of translators from fear of the com- puter to a full realization and acceptance of all it can do to help them.

The first mention of the computer (META, Vol. 11, No 3, September 1966) was the publication of a communique from the Toronto Globe and Mail, announcing the development by Kathleen H.V. Booth of the University of Saskatchewan of a programme for the computer to enable it to make rough translations of printed material from English to French. The very title of the communique "World Automation: The Bilingual Computer" and the first paragraph :

A woman mathematician at the University of Saskatchewan is teaching a computer to become bilingual, says today's Toronto Globe and Mail

seem to be snide remarks about a tool that most translators feared at the time. This fear is confirmed by the next text on the subject of computers (META, Vol. 12, No 2, June 1967), which bears the title "Ordinateur contre traducteurs" and which, on the basis of a press dispatch by the United Press International, reassures translators that they will not be replaced in the near future by computers :

Une dépêche de la United Press International, parue récemment dans les journaux, contribuera peut-être à donner un regain de confiance aux traducteurs qui doutent des ressources de leur matière grise. [...] le National Research Council des États-Unis a recommandé qu'on s'en tienne pour le moment aux méthodes traditionnelles de traduction.

However this text concludes by warning translators that research in machine translation will be pursued at the cost of millions of dollars annually and that this is not the last they have heard of the computer. And exactly a year later (June 1967), META, under the title "Encore la machine a traduire", reports on the success of experiments by IBM in RussianEnglish and Chinese-English translation

This seems to mark the end of short, snide remarks or almost patronizingly reassuring texts on the translation capabilities - or lack of them - of computers. The next text on the subject on machine translation (Vol. 12, No 3, September 1967) is a report of a symposium on the subject organized by the Société des traducteurs et interprètes du Canada, which was attended, we are told, by seventeen private enterprises as well as by translators from across Canada. The principal speakers, Susumu Kuno and Ernest Faubert, provided the participants with moderate, balanced views : machine translation is a longterm project ; it will always be less well done than human translation; machine translation will always require human intervention; and, most importantly, the computer will be of more use for linguistic research than for translation per se. 
Once the potential of the computer was seen, the attitude towards it changed. Further news of developments in machine translation at the end of the 1960's (e.g. Normand Bernier, "la France à l'avantgarde de la traduction automatique", META, Vol. 13, No 1, March 1968 ; "la Traduction automatique dans le monde" and la Traduction automatique au Canada", META, Vol. 14, No 2, June 1969) are straightforward accounts, even containing a certain optimism concerning the usefulness of the computer.

Depuis le début de 1969, on entend de plus en plus parler de traduction automatique. Il est certain que les recherches qui se poursuivent depuis des années vont enfin aboutir. [...] Le produit sera très rudimentaire et devra être révisé intelligemment. Toutefois, ce handicap n'empêchera pas la machine d'alléger de beaucoup le travail des traducteurs qui ne suffisent plus à la tâche. (META, Vol. 14, № 2 , June 1969.)

This different, more open attitude towards the computer and its use to translators is maintainer in a spate of subsequent articles on terminology banks (e.g. A. Clas, "la Banque de terminologie", META, Vol. 14, No 4, 1969 ; J.-P. Vinay, "Utilisation électronique de la Banque des mots", META, Vol. 16 , Nos 1-2, March-June 1971), although, of course, a slightly sour note does creep in once in a while, as in J.A. Bachrach's paper "l'Ordinateur au service du terminologue : maître ou esclave" (META, Vol. 16, Nos 1-2), where, in fact, the theme is the "profit que l'on peut tirer de l'emploi de l'ordinateur dans l'évaluation d'un système de consultation automatique des dictionnaires, le système DICAUTOM..."

À notre époque, nous sommes tellement habitués à nous servir de divers appareils et machines pour l'accomplissement de maintes tâches pénibles ou fastidieuses que nous oublions parfois les servitudes visibles et invisibles que cela comporte. Les avantages qu'ils offrent ne sont réels que dans la mesure où ils marchent sans défaillir. Les automates nous permettent d'accomplir plus dans un laps de temps donné, mais ils contribuent aussi à l'accélération $d u$ rythme de la vie, ce qui nous oblige à nous spécialiser toujours davantage. Si paradoxal que cela puisse paraitre, toutes ces extensions de nos moyens d'action dont parle MacLuhan, ne semblent pas avoir contribué à la diffusion du savoir universel, mais plutôt à la formation d'experts confortablement installés dans leur propre champ d'activité. Ils font usage des machines, mais ils ne se soucient en général que fort peu des détails de leur fonctionnement. $E t$ tout va très bien pour autant qu'elles continuent à marcher sans faiblesse. Lorsqu'une panne mécanique intervient, toute l'activité s'arrête en attendant la venue de cet autre spé- cialiste qu'est le technicien. Mais, attendre le technicien équivaut souvent à attendre Godot !

But in his conclusion Bachrach makes it clear that the machine is an exemplary servant, so long as man has the necessary discipline and rigour to programme it as required. The large-scale fear of computers had indeed been laid to rest - man controls the machine and not the reverse - and META continues in the following years to reflect the growing interest in and enthusiasm for term banks and computer-aided translation through serious articles. This interest and enthusiasm culminated in the special issue of March 1981, whose French title l'Informatique au service de la traduction clearly indicates that the role of the computer in translation has now become clear : it is seen as an aid and not as a rival. This is confirmed by the very first paragraphs of Alan K. Melby"s article "Translators and machines - Can they Cooperate?" published in this special issue :

Despite early fears and thirty years of work on machine translation, very few human translators have been replaced by computers. The METEO system (Chandioux 1976), one of the most successful machine translation efforts, still uses humans to translate problem sentences. The computer translates only the straightforward portions of daily weather forecasts, which become extremely boring work for human translators.

The time has finally come when translators and machines can call a truce and begin an era of significant cooperation, machines can become servants rather than enemies.

If translators have overcome their fear and suspicion of computers - their greatest bugbear in the past - and have even learned to use them happily, they can probably change their attitude toward most things. Translators, in fact, are a very adaptable group of individuals by the very fact that they change subject matter and texts daily in the course of their translation activities. They have already adjusted to many changes as trans-translation has grown and developed both in Canada and abroad and the evolution of translation, far from discouraging them, seems to have led to a greater, more generalized interest in reflecting on translation, and to an embracing of new fields as the scope of translation has broadened. Translators have learned and grown, along with the profession and discipline. This is what comes through loud and clear in the thousands of pages of META, which is a mine of information on all aspects of translation.

RODA P. ROBERTS

* Communication ACLA, 1984. 